\title{
Adrenal histoplasmosis: an uncommon presentation with an ulcer of the tongue
}

\author{
Mathews Edatharayil Kurian (D) ,' Felix K Jebasingh, ${ }^{1}$ Thomas Alex Kodiatte, ${ }^{2}$ \\ Nihal Thomas ${ }^{1}$
}

'Department of Endocrinology, Diabetes and Metabolism, Christian Medical College Vellore, Vellore, Tamil Nadu, India

${ }^{2}$ Department of Pathology, Christian Medical College Vellore, Vellore, Tamil Nadu, India

\section{Correspondence to}

Dr Felix K Jebasingh;

felixjebasingh@msn.com

Accepted 17 June 2021
Check for updates

(c) BMJ Publishing Group Limited 2021. No commercial re-use. See rights and permissions. Published by BMJ.

To cite: Kurian ME, Jebasingh FK, Kodiatte TA, et al. BMJ Case Rep

2021:14:e244296

doi:10.1136/bcr-2021-

244296

\section{DESCRIPTION}

We report the case of a 73-year-old man who presented with a history of intermittent, episodic fever and of decreased appetite, citing a weight loss of $5 \mathrm{~kg}$ over a 6 -month period. This was also associated with a central lesion over the posterior part of the tongue, appearing 6 months before. $\mathrm{He}$ also has a history of having experienced intermittent dizziness and dyspepsia. There were no other known comorbid chronic illnesses or history of tuberculosis. Besides confirming the presence of a nodular lesion on the posterior part of the tongue (figure 1), examination also revealed prominent lingual tonsils and hepatosplenomegaly. Biochemistry showed that he had hyponatraemia $(130 \mathrm{mEq} /$ $\mathrm{dL}$ ) with an inappropriately low cortisol response under stress $(13 \mu \mathrm{g} / \mathrm{dL})$ with high plasma adrenocorticotropic hormone levels $(159 \mathrm{pg} / \mathrm{mL}$; normal: 5-46). A CT scan of the abdomen demonstrated bilateral hypodense lesions with heterogeneous contrast enhancement replacing the adrenal glands (figure 2). An MRI of the abdomen confirmed bilaterally enlarged, heterogeneously hypointense adrenal lesions measuring $30 \times 22 \mathrm{~mm}$ on the right gland and $36 \times 21 \mathrm{~mm}$ on the left gland, respectively. A biopsy from the lesion on the tongue demonstrated macrophages containing intracellular, round-to-oval capsulated small-sized (3-5 $\mu \mathrm{m})$ yeast-like fungus that resembled Histoplasma capsulatum (figure 1), confirming the diagnosis. $\mathrm{He}$ was initiated on oral prednisolone, fludrocortisone and itraconazole and continued to be asymptomatic during the remainder of his stay at the hospital. He was subsequently discharged and remains on follow-up. Histoplasmosis, caused by $H$. capsulatum, is usually asymptomatic, but may occasionally present as severe illness. Despite the sparseness of literature that hinders an accurate estimate

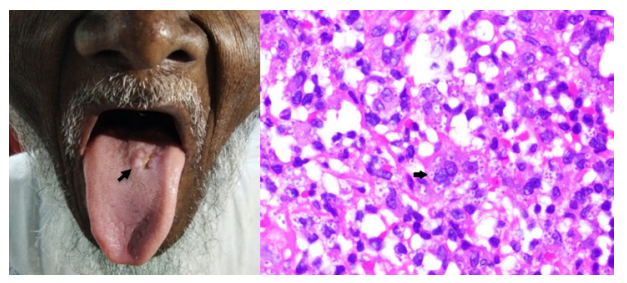

Figure 1 (L) An elevated, nodular central lesion seen on the tongue (indicated with an arrow); (R) histopathology of which demonstrated macrophages containing intracellular, round-to-oval capsulated small-sized (3-5 $\mu \mathrm{m}$ ) yeast forms (seen at the arrow) that resembled Histoplasma capsulatum (H\&E, 400x).

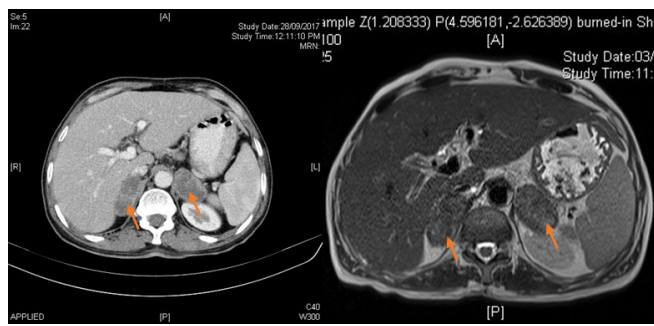

Figure 2 (L) A CT scan of the adrenal glands showing bilateral hypodense lesions with heterogeneous enhancement (shown with arrows); (R) MRI of the abdomen showing bilaterally enlarged, heterogeneously hypointense adrenal lesions (shown with arrows), measuring $30 \times 22 \mathrm{~mm}$ and $36 \times 21 \mathrm{~mm}$ on the right and left sides, respectively.

of worldwide prevalence, previous reports have suggested that it may be endemic to parts of eastern India. ${ }^{12} \mathrm{~A}$ recent review has shown increased reporting of identified cases from India. ${ }^{3}$ Future prospective studies may aid better understanding of the epidemiology. Although pulmonary histoplasmosis is the most common type of presentation, chronic haematogenous dissemination frequently takes place in immunocompromised states. ${ }^{4}$ The adrenal glands are commonly involved; however, overt adrenal insufficiency is uncommon. Oropharyngeal involvement is reported in at least $30 \%$ of cases. ${ }^{5}$ These lesions have clinical significance and early biopsy can prevent diagnostic delay. ${ }^{67}$

Contributors MEK composed the manuscript. FKJ, TAK and NT provided critical review and revised the manuscript.

Funding The authors have not declared a specific grant for this research from any funding agency in the public, commercial or not-for-profit sectors.

Competing interests None declared.

\section{Learning points}

In the presence of bilateral adrenal enlargement, it is important to consider histoplasmosis as a potential differential diagnosis.

- While the disseminated form of histoplasmosis has been described commonly in patients in immunocompromised states, it does not rule out its occurrence in others without this predisposition.

- Early biopsy of a suspect oropharyngeal lesion may prevent diagnostic delay. 
Images in...

Patient consent for publication Not required.

Provenance and peer review Not commissioned; externally peer reviewed.

3 Gupta A, Ghosh A, Singh G, et al. A Twenty-First-Century perspective of disseminated histoplasmosis in India: literature review and retrospective analysis of published and unpublished cases at a tertiary care hospital in North India. Mycopathologia 2017;182:1077-93.

ORCID ID

Mathews Edatharayil Kurian http://orcid.org/0000-0003-0822-6760

4 Kauffman CA. Histoplasmosis: a clinical and laboratory update. Clin Microbiol Rev 2007:20:115-32.

5 Goodwin RA, Shapiro JL, Thurman GH, et al. Disseminated histoplasmosis: clinical and pathologic correlations. Medicine 1980;59:1-33.

\section{REFERENCES}

1 Antinori S. Histoplasma capsulatum: more widespread than previously thought. Am J Trop Med Hyg 2014;90:982-3.

2 Goswami RP, Pramanik N, Banerjee D, et al. Histoplasmosis in eastern India: the tip of the iceberg? Trans R Soc Trop Med Hyg 1999;93:540-2.

6 Pincelli T, Enzler M, Davis M, et al. Oropharyngeal histoplasmosis: a report of 10 cases. Clin Exp Dermatol 2019;44:e181-8.

7 Choudhury TA, Baruah R, Shah N, et al. Disseminated histoplasmosis presenting as oropharyngeal mass lesion. Med Mycol Case Rep 2019;24:78-81.

Copyright 2021 BMJ Publishing Group. All rights reserved. For permission to reuse any of this content visit

https://www.bmj.com/company/products-services/rights-and-licensing/permissions/

BMJ Case Report Fellows may re-use this article for personal use and teaching without any further permission.

Become a Fellow of BMJ Case Reports today and you can:

- Submit as many cases as you like

Enjoy fast sympathetic peer review and rapid publication of accepted articles

- Access all the published articles

Re-use any of the published material for personal use and teaching without further permission

Customer Service

If you have any further queries about your subscription, please contact our customer services team on +44 (0) 2071111105 or via email at support@bmj.com.

Visit casereports.bmj.com for more articles like this and to become a Fellow 